\title{
Chapter 9 The Conversion of Reparations into Sovereign Debts (1920-1953)
}

Pierre d'Argent"

\section{Morality, Law, and the Economists}

As an early critique of the Versailles settlement, notably because of the inclusion of war pensions as head of damage, ${ }^{1}$ John Maynard Keynes foresaw the economic unsustainability of the overall reparation regime and famously wrote, 'International morality, interpreted as a crude legalism, might be very injurious to the world.' ${ }^{2}$

That sentence says it all: after the first total war of modern times during which all classes of citizens had been called to fight and to die; after a war that was for the first time not left to professional soldiers; after an industrialized war of unprecedented scale; after a war that invented war cemeteries and implanted them in the European landscape for centuries to come-after such a war, the demands of morality were running high.

Those demands were turned into law through a treaty that was imagined to be a founding stone of a lasting peace. However, there is only so much that law can achieve and deliver, and it was later for the economists and the financiers to fix the sort of monster that politicians and diplomats, turned legislators of peace, had invented. Indeed, the history of the interwar period in relation to the reparation issue makes a fascinating story that mixes together the insistence of complying with legal obligations (after all, pacta sunt servanda), how hurtful such insistence can be for the creditor itself, and the disillusion stemming from unmet naive legal expectations. It also provides an important point of departure in world history because it is then that, progressively, a professional class of experts - the economists-

* Professor at the University of Louvain (UCL), Associate Member of the Institute of International Law, Member of the Brussels Bar.

1 Such inclusion doubled the reparation claim. After lengthy debates between the Allied Powers at Versailles, it was finally included in order to satisfy the demands of the United Kingdom and the Commonwealth nations since most of the material destruction occurred in Belgium and Northern France: see Pierre d'Argent, Les réparations de guerre en droit international public (Bruylant and LGDJ 2002) 66-68.

2 John Maynard Keynes, The Collected Writings (CUP 1978) vol 3, 94. 
took over and intellectually dominated the rest of the $20^{\text {th }}$ Century, replacing morality turned into law by pragmatism and finance.

\section{The Magnitude of the German Reparation Debt}

The history covered by this contribution begins just after the 1921 London Schedule of Payments by which the Reparation Commission decided that the German reparation debt amounted to 132 billion gold marks. According to the Schedule, that sum was to be paid in various instalments until $31^{\text {st }}$ March ... 1988. ${ }^{3}$ The political confidence in a stable and predictable future stemming from such a schedule of payment seems simply incredible today: it is as if we would make plans today about the repayment of the Greek debt until 2085. Furthermore, 132 billion gold marks is a very abstract figure.

In order to measure the magnitude of the reparation debt, not only over time but also in economic terms, it is useful to put it in today's value: 132 billion gold marks is the equivalent of about 450 billion in today's US dollars, ${ }^{4}$ an amount close to today's GDP of countries such as Belgium or Austria. ${ }^{5}$ In 1913, Germany's GDP was approximately 441 billion in today's US dollars. ${ }^{6}$ In other words, 132 billion gold marks was a claim equivalent to the German pre-war GDP. To put it differently, under Versailles, Germany was supposed to transfer to its creditors an amount equivalent to the market value of all final goods and services produced in Germany in one year just before the war. Of course, that was to be diluted over 67 yearsbut it is still a huge amount.

To make it even more concrete, consider the following: in 2017, the total education budget of Germany was approximately 20.7 billion dollars. ${ }^{7}$ In other words, the 132 billion gold marks to be paid by Germany under the Versailles reparation scheme roughly amounts to 22 years of today's German expenditure for education. Economically speaking, claiming 132

3 'The Reparation Commission to the German War Debt Commission, Paris, 28 April 1921' (1922) 16 AJIL Supp 214. The London Schedule of payment divided the German debt into A, B and C bonds and Germany was actually only required to pay the first two categories of bonds, totalling 50 billion gold marks.

$4<$ www.westegg.com/inflation> accessed 14 June 2018.

$5<$ https://data.worldbank.org> accessed 14 June 2018.

6 ibid.

7 Or EUR 17.6 bn : <https://www.bmbf.de/en/education-and-research-priority-areasof-federal-government-policy-1410.html> accessed 14 June 2018. 
billion gold marks is the same as requesting today, that during a whole generation, Germany be turned into a pastoral country of uneducated citizens; or, if payments are postponed until 2085, to request that the German education budget be cut by a third for the next 67 years.

It is no surprise that Versailles has been characterized as 'economic vivisection:8

\section{The Rubr Crisis and the Dawes Plan}

In January 1923, after Germany stopped certain deliveries, the new French government of Poincaré requested productive guarantees for German payments, which was rejected by Britain. French and Belgian troops entered and occupied the Ruhr region. The purpose of the occupation was to seize, as a means of direct payment, part of the German coal and industrial output.

Of course, France and Belgium pretended to act in accordance with the Versailles Treaty provisions, while the United Kingdom and Germany disagreed. However, as Charles De Visscher aptly put it, the legal argument was a 'caustic dead end.' Indeed, the fact of the matter was that the creditors had fatally wounded their debtor. While, in April 1923, one gold mark was worth about 6000 marks used in the real economy, it was worth 1 trillion (ie 1000 billion) marks in December of the same year. Collecting the needed gold marks to comply with the London Schedule of Payment became simply impossible after such an unmatched devaluation of the currency-unmatched devaluation that is still part of the collective political imagination in Germany and explains its obsession about having the containment of inflation through price stability as the core policy objective of the European Central Bank. ${ }^{10}$ The past is so much present.

Chancellor Cuno was replaced by Stresemann, who decided to end passive resistance in the Ruhr, and a return to a negotiated settlement was agreed. In November 1923, the Reparation Commission appointed a com-

8 John Wheeler-Bennett, The Wreck of Reparations: Being the Political Background ofthe Lausanne Agreement (Allen \& Unwin 1932) 255.

9 Charles De Visscher 'Revue des revues' (1924) 5 Revue de droit international et de législation comparée 469,476 . On the debate relating to the legality of the Ruhr occupation, see also Étienne Weill-Raynal, Les réparations allemandes et la France (Nouvelles Éditions Latines 1947) vol 2, 368-383.

10 See Treaty on the Functioning of the European Union (signed 13 December 2007, entered into force 1 December 2009) [2008] OJ C115/47, arts 127 and 140. 
mittee chaired by the United States General Charles Dawes, who was tasked with the return of monetary stability in Germany.

The Dawes plan is a complex set of five interrelated agreements approved in London on 16 August $1924 .{ }^{11}$ The basis of the Dawes plan was the return to German fiscal and economic unity, which meant the end of the Ruhr occupation. The basic novelty of the Dawes plan was to distinguish between the capacity of Germany to pay reparation and the transfer of massive wealth to the creditor nations. Under the Dawes plan, Germany was made to pay yearly instalments partly defined by a prosperity index, which were designed to include all debts owed by Germany under the Versailles Treaty. What was precisely included in those instalments was subject to interpretation by the Reparation Commission established pursuant to Article 232 of the Versailles Treaty. ${ }^{12}$ The Reparation Commission issued several awards, the details of which are unimportant here. ${ }^{13}$ What is important, however, is to recall that the German payments were made by Germany in German currency and in Germany, to an account open in the books of a profoundly reformed Reichsbank, in the name of the 'AgentGeneral for Reparation Payments.

The purpose of such internal collection of debt and the avoidance of a massive international transfer of wealth was to prevent an increased competition by German manufacturers on the world market. Indeed, as it was said at the time of Versailles by economists critical of the settlement, deciding on the amount of reparation exacted from Germany was actually, in economic terms, deciding on the extent of the services that the creditor nations were willing to see Germany render to the world. In other words, prior to the Dawes plan, the reparation payments made by Germany were actually detrimental to their legal beneficiaries: indeed, in order to pay the various instalments in the currencies of the creditor nations, Germany had to compete on world markets with the producers from those beneficiary nations, therefore limiting their own exports and creating economic downturn at home while turning Germany into the 'workshop of the world'.

11 See Charles Dawes, A Journal of Reparations (MacMillan 1937). For the text of the 1924 London Agreements incorporating the Dawes plan, see Final Protocol of the London Conference (16 August 1924) 41 LNTS 429. For references and details about the Dawes plan, see d'Argent (n 1) 91-95.

12 See Halpérin (ch 8).

13 Interpretation of London Agreement of August 9, 1924: Awards Nos 1 (24 March 1926) 2 (29 January 1927) and 3 (29 May 1928) 2 RIAA ch XXI, 873-899. See John Fisher Williams, 'The Tribunal for the Interpretation of the Dawes Plan' (1928) 22 AJIL 797. 
Over time the Dawes plan worked: economic stability, together with German capital that had fled during the Ruhr inflation times, was brought back to Germany. At the same time, the political mood had changed for better: the pact of Locarno was concluded in 1925, Germany joined the League of Nations in September 1926, the Kellogg-Briand pact was concluded in Paris in 1928.

Because the Dawes plan remained open-ended while, legally speaking, leaving the London Schedule of payments unaffected, the need was felt to finally settle the reparation debt issue in order to achieve financial predictability and prolonged stability. Furthermore, the European creditors of Germany came to realize that the sums of money collected by Germany and transferred to the victorious belligerents through the Agent-General were immediately used in their national budgets to pay back the loans they had contracted with the United States during the conflict in order to sustain their war effort. In a way, and in light of the financial cycle by which the payments received from Germany were immediately used to repay United States war loans, the reparation payments did not really make good on any damage in the countries that had suffered from the German invasion. ${ }^{14}$

Therefore, the European creditors felt that it was the right time to change the Dawes plan into a final settlement, which would link what was legally distinct but financially linked, ie the German reparations and the repayment of the United States war loans.

\section{The Young Plan and Its Aftermath}

Under the leadership of Owen D Young, who was a former member of the Dawes committee and former Agent-General, a committee of independent experts jointly appointed by the Reparation Commission along with, the United States Government and, for the first time, the German Government issued a report on 7 June 1929. The Young report was approved in The Hague on 20 January 1930 and incorporated in treaty law. ${ }^{15}$

14 See d'Argent (n 1) 95-96.

15 Agreement regarding the Complete and Final Settlement of the Question of Reparations (with Annexes) (signed 20 January 1930) 104 LNTS 243; Arrangement as to the Financial Mobilisation of the German Annuities (with Annex) (signed 17 January 1930) 104 LNTS 243. On the Young plan, see eg, A Pépy, 'Après les ratifications du Plan Young: Révision et sanctions' (1930) 5 Rev Dr Int 441-477; GA Finch, 'The Settlement of the Reparation Problem' (1930) 24 AJIL 
Under the Young plan, the Reparation Commission was dissolved, together with various guarantee mechanisms under the Dawes plan. The Bank for International Settlements, an institution that still exists, ${ }^{16}$ was established as trustee of the creditor nations and tasked with allocating to each of them new yearly instalments.

According to the Young plan, during a first period of 37 years, ending in 1966, each German instalment was composed of two parts: on the one hand, an unconditional part (about one third of the total due) and, on the other hand, a deferrable part that Germany could decide to postpone in case of economic hardship. After 1967, the instalments due until 1988 were only made up of the deferrable part. That part incurred interests and was financed by a consortium of United States banks coordinated by JP Morgan.

That latest, deferrable part of the instalments corresponded to the sums needed for the service of the inter-allied war loans. In such a way, Germany was somehow subrogated in the obligations owed by its war reparation creditors to the United States. A link between war reparations and inter-allied war loans was thus established, but it was not specifically agreed that the postponement by Germany of the variable part of the instalments would authorize the European powers to suspend the service of their debts to the United States. However, it was agreed that if the United States were to cancel or reduce the war loans, Germany would automatically benefit from it.

In addition, 'reparation bonds' were issued on the deferrable part of the instalments in order to cash-in and depoliticize the payment issue. Financial instruments were used and 'the public' (ie individuals, banks and corporations), instead of States, became creditors of Germany by purchasing those bonds that could be exchanged and traded on the world market.

Under its own terms, the Young plan was a complete and final settlement of the financial issues that arose out the Great War; it operated a kind of juridical novatio for all the previous conventional arrangements-however, without prejudice to Article 231 of the Versailles Treaty which remained unaffected.

The Young plan entered into force in May 1930, but very soon the disastrous economic consequences of the 1929 financial crisis were felt and Germany requested a new moratorium on its obligations. In August 1931,

339-350; Chandler P Anderson, 'Final Liquidation of German War Reparations' (1931) 25 AJIL 97-101; and also the references in d'Argent (n 1) 97.

$16<$ www.bis.org> accessed 14 June 2018. 
such a moratorium was agreed by United States President Hoover for one year, and it applied on all interstate payments, be them of reparation or for war loans. A new revised plan was designed in Lausanne in July 1932. Most of the Young plan was to be terminated and replaced by the issuance by Germany of tradable bonds for total value of 3 billion gold Reich marks, with $5 \%$ interest. ${ }^{17}$

However, the Lausanne agreement never entered into force because Belgium, France, Italy and the United Kingdom agreed to postpone its ratification 'until a satisfactory settlement has been reached between them and their own creditors, ${ }^{18}$ ie the United States. Such settlement of the war loans issue never occurred and the Lausanne agreement failed to replace the Young plan. However, Germany considered that a new situation had arisen since the Young plan was not brought back in full force, and it called for a new diplomatic conference.

This conference never met: on 30 January 1933, Hitler became Chancellor and very soon suspended the payments, including the service of the reparation bonds that were constituted as private legal titles, distinct and separate from the interstate debts. As a matter of law, the bonds remained unaffected by the legal uncertainties surrounding the legal status of the Young plan resulting from the failed Lausanne settlement.

After the Second World War, the 1953 London Agreement on German External Debts ${ }^{19}$ deferred sine die the settlement of the World War I governmental claims while the World War II claims were deferred until German reunification. As far as the latter are concerned, the Bundesverfassungsgericht (BVerfG) has interpreted the Two Plus Four Agreement of $1990^{20}$ that paved the way to German reunification as putting an end to the deferral of World War II claims. ${ }^{21}$

As far as the World War I reparation bonds issued on the world market are concerned, Annex I of the London Agreement of 1953 set out a com-

17 See d'Argent (n 1) 100-103, with references.

18 'Procès-verbal relating to the Ratification of the Agreement concerning German Reparations, Lausanne, 2 July 1932' in Manley O Hudson (ed), International Legislation (vol 6, Carnegie Endowment 1937) no 311b, 83.

19 London Agreement on German External Debts (signed 27 February 1953, entered into force 16 September 1953) 333 UNTS 3.

20 Treaty on the Final Settlement with Respect to Germany (signed 12 September 1990, entered into force 15 March 1991) 1696 UNTS 115 (Two Plus Four Agreement).

21 BVerfG, 13 May 1996, 94 BVerfGE 315. There is no need to enter here into a discussion about the adequacy of such understanding of the Moscow Treaty: on that issue, see d'Argent (n 1) 220-228. 
plex scheme of gradual payments with deferred maturities and interests rates. Arbitration was initiated in 1979 against Germany by Belgium, France, Switzerland, the United Kingdom and the United States about the Young plan loans and the interpretation of depreciation provisions in the Agreement after the revaluations of the Deutsche Mark in 1961 and 1969. ${ }^{22}$ Overall, the bonds were roughly paid back by 1983 . One outstanding debt relating to the service of interest over a loan contracted by the Weimar republic to finance war reparation instalments was finally paid back after German reunification, with a final payment in October 2010, some 92 years after Versailles. ${ }^{23}$

\section{The Versailles Reparations in Perspective}

From such long and complex history, what can be gathered?

First, as we know from personal experience through our own mortgages and bank debts, finance is an incredible time machine since it helps to get cash now, while deferring the service of the debt to a later point thanks to a promise solidified in a private law instrument, ie a contract. It also confirms what everybody suspects: while it seems to depoliticize governmental debts by diluting them into the anonymity of the public, resorting to financial instruments paradoxically make debts stronger and more lasting over time. It is a lesson of humility for public international lawyers: on the long term, private law instruments are more resilient and beat public law instruments. The reason for this is probably due to the subjects at stake, ie the anonymity that goes with the market and the exchange of privately owned bonds. After all, who is a 'bond bearer' that needs to be serviced? It could be anyone, including German citizens themselves.

Second, public international law builds states as abstract legal entities having debts vis-à-vis each other, and it only governs the debt obligation.

22 Case concerning the question whether the re-evaluation of the German Mark in 1961 and 1969 constitutes a case for application of the clause in article 2 (e) of Annex I A of the 1953 Agreement on German External Debts between Belgium, France, Switzerland, the United Kingdom of Great Britain and Northern Ireland and the United States of America on the one hand and the Federal Republic of Germany on the other (decision of 16 May 1980) 19 RIAA 67-145.

23 David Crossland, 'Germany Closes Book on World War I With Final Reparations Payment (Spiegel Online, 28 September 2010) <www.spiegel.de/international/ germany/legacy-of-versailles-germany-closes-book-on-world-war-i-with-final-reparations-payment-a-720156.html> accessed 14 June 2018. 
However, it is absolutely blind and wants to ignore the issue of the contribution to the debt. The civil law distinction between the obligation à la dette and the contribution à la dette does not exist in international law. International law does not pierce the veil of sovereignty, and how states collect the debt domestically is of no interest to international law. Moreover, international law is premised on the paradigm of state continuity. So, as a matter of principle and if we think abstractly as international law invites us to do, over an infinite period of time, even the poorest nation on the planet has, theoretically speaking, an unlimited capacity to pay. In other words, the state remains, it is always the same, and a huge sum of money can always be paid through instalments stretching over a huge number of years. However, Versailles teaches us that such oversimplifications are unsustainable in real life: paying odious debts generation after generation simply does not make sense, politically speaking. Therefore, despite the fine legal abstractions built by international law, time-time that governs our own lives - is of the essence. Therefore, when designing reparation regimes for historical events, time should never be ignored. If the temporal dimension of war settlements is ignored, it can be feared that, to paraphrase Keynes by swapping morality for legality, 'International legality, interpreted as a crude moralism, might be very injurious to the world? 
